\title{
Erratum untuk: Pengembangan Aplikasi Assessment Menggunakan Media Short Message Service
}

\author{
Guruh Sukma Hanggara*, Santy Andrianie, Restu Dwi Ariyanto \\ Program Studi Bimbingan dan Konseling, Fakultas Keguruan dan Ilmu Pendidikan, \\ Universitas Nusantara PGRI Kediri, Jl. K.H. Ahmad Dahlan No. 76, Kediri, Jawa Timur, 64112, Indonesia \\ *Penulis koresponden, e-mail: kangguruh@gmail.com
}

Kami memohon maaf atas kesalahan penulisan Digital Object Identifier (DOI) pada artikel dengan judul Pengembangan Aplikasi Assessment Menggunakan Media Short Message Service. DOI artikel yang tertulis "https://doi.org/10.17977/um001v3i42018p146" pada halaman 146 di bagian cara merujuk, seharusnya tertulis: https://doi.org/10.17977/um001v3i32018p146. Artikel asli telah diperbaiki. 